\title{
Spatio-temporal variation of male sterile frequencies in two natural populations of Beta maritima
}

\author{
V. Boutin-Stadler, \\ P. Saumitou-Laprade, \\ M. Valero, \\ R. Jean and \\ Ph. Vernet
}

Laboratoire de Génétique Ecologique et de Biologie, des Populations Végétales, U.A. CNRS 1185, Université des Sciences et Techniques de Lille, Flandres Artois, F-59655 Villeneuve d'Ascq cedex, France.

\begin{abstract}
The spatio-temporal variation of sex phenotype frequencies is investigated within two gynodioecious populations of Beta maritima located along the English Channel, in which the proportions of females differ significantly: $0 \cdot 19$ (Population A) and 0.62 (Population B). A genetical analysis of maternal progenies obtained from in situ openpollinated plants $\left(G_{1}\right.$ generation) allows us to define two types of parents: segregating plants (females, intermediatefemales and some hermaphrodites) which yield different types of progenies, and non-segregating plants, hermaphrodites which yield only hermaphrodites. Molecular analysis (Saumitou-Laprade, 1989) confirms the results of a preliminary study (Boutin et al., 1987), in which it is shown that cytoplasmic type is related to segregation in the maternal progeny.

A differentiation in space has been pointed out by the comparison between the sex phenotype frequencies in the two populations. This differentiation is not due to a variation of cytoplasmic frequencies but to a variation in the nuclear genetic components of these populations: the level of restoration is higher in population $\mathbf{A}$ than in population $B$.

A comparison of the $G_{0}$ and $G_{1}$ generations did not allow to predict any detectable temporal change in population $A$, whereas the frequency of females in population $B$ has been predicted to decrease quickly, probably due to a rapid invasion of restorer genes. We suggest that pollen flow is an important factor which determines the rate of the dynamics of male sterility during the life-span of a population.
\end{abstract}

\section{INTRODUCTION}

In natural populations of several wild plant species, nucleo-cytoplasmic determination of male sterility appears to be much more common than purely nuclear determination (e.g., Origanum vulgare, Kheyr-Pour, 1980; Plantago lanceolata, Van Damme, 1983; Thymus vulgaris, Dommée, 1973). The intraspecific variation in the frequency of female (=male sterile) plants results from the interaction of hereditary information from two sources, nucleus and cytoplasm, leading to the formation of either female or hermaphrodite phenotypes. Several models (see Ross, 1978, for review; Gregorius et al., 1982) based on purely nuclear control of gynodioecy have failed to explain the diversity of observed situations (particularly, female frequencies higher than 50 per cent and only a slightly higher female fitness of females than hermaphrodites), whereas they can be explained by nucleo-cytoplasmic models (Delannay et al., 1981; Gouyon and Couvet, 1985; Couvet et al., 1986). In self-compatible species, a stable equilibrium of the frequency of females, if it exists, is reached slowly with oscillations of the frequency of females (Charlesworth, 1981). In selfincompatible species, stable limit cycles between the frequency of cytoplasmic and nuclear genes are usually found (Gouyon et al., in preparation; Boutin-Stadler et al., in preparation). Thus, proportions of sex phenotypes have been expected to change over time. The occurrence of genetic differentiation among populations can be explained both by isolation among populations and by the interactions between nuclear and cytoplasmic genes determining male-sterility: when a new site is founded by hermaphrodites and females, female frequency in later generations will depend on whether or not the hermaphrodites possess the restorer genes of the cytoplasms of the female plants.

The variation of sex phenotype frequencies has often been studied indirectly by comparing populations situated in different successional stages of the vegetation (Dommée et al., 1983; Gouyon et al., 1983; Dommée and Jacquard, 1985; Balhassen 
et al., in press). Less frequently, variation has been followed over time within populations. For example, in such a study, marked decrease in female frequencies was observed by Krohne et al. (1980) in Plantago lanceolata from one year to the next.

In Beta maritima, the available data indicate that the male sterility system, although similar to that studied by Owen (1942) in cultivated sugar beet, has different nuclear and cytoplasmic components (Boutin et al., 1987; Boutin et al., 1988a; Halldén et al., 1988). In the populations studied a strong correlation exists between the type of cytoplasm and the presence or the absence of segregation of females in the progenies (Boutin-Stadler, 1987; Boutin et al., 1988b; Saumitou-Laprade, 1989).

In this paper, we first study the variation of sexual phenotype frequencies in space by comparing two populations of Beta maritima. The differences observed among the segregations in the progenies of plants from these populations give us an insight in their genetic structure and enable a rough estimate of the level of restoration. Secondly, we study the variation of sex phenotype in time, that is whether these populations are in an equilibrium stage by comparing the observed sex phenotype frequencies in situ (referred to as the $G_{0}$ generation) with the expected ones in the $\mathrm{G}_{1}$ generation.

\section{MATERIAL AND METHODS}

\section{Plants of the $G_{0}$ generation and their open-pollinated progenies}

The two Beta maritima populations, called $\mathrm{A}$ and $B$, are located in the higher zone of a salt marsh in the Canche estuary (northern France). They are covered by the sea at the time of equinox springtides. They are separated by a distance of $1 \mathrm{~km}$. Population $\mathrm{A}$ is located at the foot of the sand dunes; in 1984, 94 flowering plants covering an area of $80 \mathrm{~m} \times 5 \mathrm{~m}$ grew in a herbaceous community. This population was surrounded by several other populations of $B$. maritima. Population $B$ is located on a small sandy mound between the salt marsh and the beach and is more often covered by the sea during heavy storms; in 1984, 66 flowering plants grew in an area approximately $40 \mathrm{~m} \times$ $10 \mathrm{~m}$, among culms of Agropyron pungens and were isolated more than 500 metres from other $B$. maritima plants.

Three sex phenotypes were distinguished in this species by using anther and pollen characteristics defined at anthesis (Boutin et al., 1987): (i) hermaphrodites $(\mathrm{H})$, with yellow stamens containing viable and functional pollen, (ii) females $(\mathrm{Fe})$, with white stamens lacking pollen grains, (iii) intermediate-females (IFe), with stamens containing microsospores and non-viable pollen grains. Each plant was observed three times during its flowering period in the natural populations or in the experimental garden of the university, in order to check the stability of the sex phenotypes: no difference appeared among the observations. Neither the females nor the intermediate-females transmit their genes through male gametes and so they are functionally females.

Fruits were harvested from a sample of individual plants (mother-plants) of known phenotype that had been pollinated in situ in each population $(16 \mathrm{H}, 11 \mathrm{IFe}$ and $6 \mathrm{Fe}$ in population $A$ and $10 \mathrm{H}, 2 \mathrm{IFe}$ and $18 \mathrm{Fe}$ in population $\mathrm{B}$ ) proportional to the number of plants of each sex phenotype in the population. That explains, for instance, the very small number of IFe families studied in population B. Seeds were sown in the experimental garden of Lille University. The 63 families ranged in size from seven to 80 individuals. The total number of plants was 1446; they formed the $G_{1}$ generation and were used for the subsequent genetic analysis.

In both populations, the $\mathrm{Fe}$ and IFe plants always produce segregating progenies (i.e., composed of two or three sexual phenotypes), whereas the $\mathrm{H}$ plants can be classified in two groups:

-the segregating ones ( $\mathrm{H}$ segr.) which generate two or three sexual phenotypes in their progenies, like the Fe and IFe plants;

- the non-segregating ones ( $\mathrm{H}$ non-segr.) which only produce $\mathrm{H}$.

A joint genetical and molecular analysis (Boutin et al., 1987; Boutin et al., 1988a; SaumitouLaprade, 1989) suggested the existence of two groups within these two populations, in which progenies of segregating plants carry the S cytotype and the progenies of non-segregating plants carry the $\mathrm{N}$ cytotype.

\section{The variation of sex phenotype frequencies between the observed $G_{0}$ and the expected $G_{1}$ generations}

The method consisted in the comparison of the sex phenotype frequencies in the in situ population samples with the ones expected in the next generation according to the segregations observed in the maternal progenies, in order to check if the sex frequencies are at equilibrium. In each population, the sex phenotype frequencies in the expected $G_{1}$ 
generation have been estimated by calculating the frequency of each sex phenotype in each progeny and taking the unweighted average over all progenies.

As the non-segregating hermaphrodites give only hermaphrodites in their offspring and as the frequency of restorer genes of the $S$ cytoplasm is not known in the non-segregating plants, the variation in time of sex phenotype frequencies will only be estimated using segregating plants.

\section{Statistical analysis}

The $G$ test of independence using William's correction (Sokal and Rohlf, 1981 p. 731) was used to test:

- the difference in sex phenotype frequency between the two natural populations (variation in space);

-the difference in frequency of the two types of hermaphrodites between the two population samples (variation of cytotype frequencies among hermaphrodites);

- the difference in cytotype frequency in the $G_{0}$ generation and the difference in the level of restoration of segregating plants (restored plants/non restored plants) between the two population samples (variation of the cytotype frequencies and variation in the level of restoration).

Within each population sample, the comparison between the sex phenotype frequencies observed in situ with the expected ones in the following generation (variation in time) was tested with a $G$ test for goodness of fit using William's correction (Sokal and Rohlf, 1981 p. 704).

\section{RESULTS}

Sex phenotypic variation between populations $A$ and $B$ (variation in space)

The sex phenotype frequencies in populations $A$ and $\mathrm{B}$ (table 1) appeared to be strongly different $\left[G_{\text {Williams(2) }}=34.56, \quad P<0.001\right]$. Population A

Table 1 Distribution of sex phenotype frequencies in populations $\mathrm{A}$ and $\mathrm{B}$ from the Canche estuary

\begin{tabular}{lllll}
\hline \multirow{2}{*}{ Population } & \multirow{2}{*}{$\begin{array}{l}\text { No. of } \\
\text { plants }\end{array}$} & \multicolumn{3}{l}{ Sex phenotypes* } \\
\cline { 3 - 5 } & $\mathrm{H}$ & $\mathrm{IFe}$ & $\mathrm{Fe}$ \\
\hline $\mathrm{A}$ & 94 & 0.48 & 0.33 & 0.19 \\
B & 66 & 0.30 & 0.08 & 0.62 \\
\hline
\end{tabular}

${ }^{*} \mathrm{H}=$ hermaphrodite; $\mathrm{IFe}=$ intermediate-female; $\mathrm{Fe}=$ female. contained few Fe plants and showed a relatively high frequency of $\mathrm{H}$ and IFe, whereas population $B$ contained many $\mathrm{Fe}$ plants and showed a low frequency of IFe.

\section{Genetical analysis of the $G_{0}$ generation}

As cytoplasmic inheritance is maternal, both the female parent and its offspring possess the same cytoplasmic type. Consequently, the structure of the samples of the two populations can be examined using both cytoplasmic and nuclear information, the latter being based on the sex phenotype of the $S$ plants: hermaphrodites possess the nuclear restorer genes and females do not possess them. In population A, in which IFe plants were numerous, segregations in the maternal progenies between phenotypic classes are significantly different $\left(\chi_{(2)}^{2}=41.29, P<0.001\right)$ : the mean hermaphrodite frequency is higher in IFe families $(0.28)$ than in $\mathrm{Fe}(0.16)$ families and is highest in segregating $\mathrm{H}$ families $(0 \cdot 47)$. These results of segregations (Boutin-Stadler, 1987) strongly suggest that IFe are partially restored.

The following points appear:

Firstly, among the hermaphrodite sampled (table 2), the frequencies of non-segregating and segregating plants, having respectively the $\mathrm{N}$ and the $\mathrm{S}$ cytoplasm, are significantly different in the two populations $\left[G_{\text {Williams(1) }}=4.90, P<0.05\right]$ : the more frequent type of $H$ is the non-segregating one in population $B$ and the segregating one in population A.

Table 2 Frequencies of segregating and non-segregating hermaphrodites in the population samples

\begin{tabular}{llll}
\hline Population & $\begin{array}{l}\text { Total } \\
\text { no. of } \mathrm{H}\end{array}$ & Segregating & Non-segregating \\
\hline A & 16 & 0.75 & 0.25 \\
B & 10 & 0.30 & 0.70 \\
\hline
\end{tabular}

Secondly, within the sample of each population (table 3), the frequency of each type of $\mathrm{H}$ can now be specified and the frequency of each type of cytoplasm can be estimated: population B contains a higher proportion of non-segregating $\mathrm{H}(0 \cdot 23)$ than population $\mathrm{A}(0 \cdot 12)$, but there is no significant difference in cytoplasm frequency between the two populations $\left[G_{\text {Williams(1) }}=1 \cdot 32, P>0 \cdot 05\right.$ ].

Thirdly, among the segregating plants (table 3 ), the frequencies of the three sex phenotypes are significantly different between the two samples $\left[G_{\text {Williams(2) }}=17.48, \quad P<0.001\right]$; the ratio of 
Table 3 Sex phenotype frequencies according to the type of segregation and the level of restoration in the samples of populations A and B. H: hermaphrodite; IFe: intermediate-female; Fe: female

\begin{tabular}{|c|c|c|c|c|c|c|}
\hline \multirow[b]{3}{*}{ Population } & \multicolumn{4}{|c|}{ Segregating plants (S) } & \multirow{3}{*}{$\begin{array}{l}\begin{array}{l}\text { Non-segregating } \\
\text { plants }\end{array} \\
\mathrm{H}\end{array}$} & \multirow{3}{*}{$\begin{array}{l}\text { Total } \\
\text { No. of } \\
\text { plants }\end{array}$} \\
\hline & \multicolumn{2}{|c|}{ Restored plants } & \multirow{2}{*}{$\frac{\text { Non-restored }}{\mathrm{Fe}}$} & \multirow[b]{2}{*}{ Total } & & \\
\hline & $\mathrm{H}$ & IFe & & & & \\
\hline $\mathbf{A}$ & $0 \cdot 36$ & $0 \cdot 33$ & $0 \cdot 18$ & 0.88 & $0 \cdot 12$ & 33 \\
\hline B & $0 \cdot 10$ & $0 \cdot 07$ & 0.60 & 0.77 & $0 \cdot 23$ & 30 \\
\hline
\end{tabular}

restored plants $(\mathrm{H}+\mathrm{IFe})$ to the non-restored plants $(\mathrm{Fe})$ is significantly higher in population $\mathrm{A}$ than in population B $\left[G_{\text {Williams(1) }}=17.60 P<0.001\right]$, and therefore the level of restoration is higher in population $A$ than in population $B$ (table 4 ).

Table 4 Variation of the restoration level* between samples of plants from populations A and B and between generations

\begin{tabular}{|c|c|c|c|}
\hline \multirow[b]{2}{*}{ Population } & \multicolumn{2}{|c|}{ Level of restoration* in } & \multirow[b]{2}{*}{$\begin{array}{l}\text { Ratio } \\
\mathrm{G}_{1} / \mathrm{G}_{0}\end{array}$} \\
\hline & $\begin{array}{l}\mathrm{G}_{0} \\
\text { In situ } \\
\text { generation }\end{array}$ & $\begin{array}{l}\mathrm{G}_{1} \\
\text { Expected } \\
\text { generation }\end{array}$ & \\
\hline A & $3 \cdot 83$ & $6 \cdot 25$ & $1 \cdot 63$ \\
\hline B & $0 \cdot 28$ & $2 \cdot 28$ & $8 \cdot 14$ \\
\hline
\end{tabular}

* Restoration level $=($ No. of restored plants: $H$ segr. + $\mathrm{IFe}) /($ No. of non-restored plants: Fe).

\section{Comparison of the expected $G_{1}$ generation with the $G_{0}$ generation (variation in time)}

The comparison of the proportions of sex phenotypes in $\mathrm{G}_{0}$ and expected $\mathrm{G}_{1}$ (table 5) reveals no difference for population $\mathrm{A}\left[G_{\text {Williams(2) }}=2 \cdot 36\right.$, $P>0.05]$ but a significant difference for population B $\left[G_{\text {Williams(2) }}=27.84 P<0 \cdot 001\right]$. The level of restoration thus increases relatively more rapidly in population $B$ which showed a higher frequency of females in the $G_{0}$ generation (table 4 ).

\section{DISCUSSION}

\section{The $\mathrm{G}_{0}$ populations (variation in space)}

Although the number of loci involved in the restoration process, their dominance, and the nature of interactions between loci are not known, it is nevertheless possible to evaluate the approximate level of nuclear restoration of the $S$ cytoplasm. Indeed, the difference in female frequency between the two populations is not related to a difference in cytoplasm frequency; thus the main difference between the two $G_{0}$ populations may be attributed to the approximate level of restoration, which was higher in population $\mathrm{A}$.

The occurrence of females in gynodioecious species (e.g., Thymus vulgaris) is interpreted as the consequence of a nucleo-cytoplasmic differentiation between populations (Couvet et al., 1985). Study of gene flow among several populations of Beta maritima (Saumitou-Laprade et al., in preparation) showed the existence of a genetic differentiation between populations, suggesting that populations were isolated from each other. These results can help us to understand the variation in sexual phenotype frequencies in our populations. Indeed the two populations differ only by the frequency of restorer genes. Population A, in the neighbourhood of other populations could more easily exchange nuclear genes with the adjacent populations compared with the isolated population $\mathrm{B}$, in which restorer genes may have appeared recently.

Table 5 Comparison of the sex phenotype frequencies among segregating plants of the population samples in the expected $G_{1}$ generation with their observed frequencies in the $G_{0}$ generation

\begin{tabular}{|c|c|c|c|c|c|c|}
\hline \multirow[b]{2}{*}{ Population } & \multirow[b]{2}{*}{ Generation } & \multirow{2}{*}{$\begin{array}{l}\text { No. of } \\
\text { plants }\end{array}$} & \multicolumn{3}{|c|}{ Sex phenotypes among $S$ plants } & \multirow{2}{*}{${ }_{P}^{G_{\text {Williams }(2)}}$} \\
\hline & & & H segr. & $\mathrm{IFe}$ & $\mathrm{Fe}$ & \\
\hline $\mathbf{A}$ & $\begin{array}{l}\mathrm{G}_{0} \\
\mathrm{G}_{1}\end{array}$ & 29 & $\begin{array}{l}0 \cdot 41 \\
0 \cdot 35\end{array}$ & $\begin{array}{l}0 \cdot 38 \\
0 \cdot 51\end{array}$ & $\begin{array}{l}0 \cdot 21 \\
0 \cdot 13\end{array}$ & $\begin{aligned} & (2.36) \\
& >0.05\end{aligned}$ \\
\hline B & $\begin{array}{l}\mathrm{G}_{0} \\
\mathrm{G}_{1}\end{array}$ & 23 & $\begin{array}{l}0.13 \\
0.09\end{array}$ & $\begin{array}{l}0.09 \\
0.61\end{array}$ & $\begin{array}{l}0.78 \\
0.31\end{array}$ & $\begin{array}{l}(27 \cdot 84) \\
<0.001\end{array}$ \\
\hline
\end{tabular}




\section{The dynamics of populations (variation in time)}

The comparison between the in situ observed $G_{0}$ populations and their respective $G_{1}$ generation enables us to test whether or not the sex phenotype frequencies were at equilibrium. It is expected that:

(i) Population $\mathrm{A}$ is not in an important shifting phase because there is no significant difference between generations;

(ii) Population $\mathrm{B}$ is undergoing major change because, in only one generation, a major decrease of females of -47 per cent was accompanied by an increase of intermediatefemales of 52 per cent.

Our data obtained from the two population samples indicate that the high proportion of females in population B may not correspond to an equilibrium state and occurs when male fertile restorer genes are rare in the population.

These data are in agreement with a model of dynamics of sex phenotype in gynodioecious populations of self-incompatible species (BoutinStadler et al., in preparation). Three phases can be described if we suppose that female (having the $\mathrm{S}$ cytotype) and hermaphrodite (having the $\mathrm{N}$ cytotype) migrants colonize a new site:

(i) Assuming a cost of restoration (that is, selection acting against hermaphrodites carrying the restorer genes of an another cytoplasm (Delannay et al., 1981; Charlesworth, 1981; Gouyon and Couvet, 1985; Gouyon et al., in preparation), in such a population, the hermaphrodites (N) rarely possess the specific restorer genes of the sterile $S$ cytotype. Because of a cytoplasmic determination of male sterility, as long as females have even a very small advantage in seed production, the female frequency will increase in the population as well as the frequency of cytotype $S$.

(ii) High female frequency in the population selects for nuclear restorer genes. Then, once introduced, restorer genes invade the $S$ cytoplasm, very rapidly at the beginning and later on more slowly, causing a decrease of female frequency in the population.

(iii) At this time, hermaphrodites having $\mathrm{S}$ cytoplasm are numerous and female frequency is low in the population. Assuming a higher female fitness of hermaphrodites having $\mathrm{N}$ cytotype compared to ones having $\mathrm{S}$ cytotype, the frequency of the former increase in the population. In the same time, due to the restoration cost, the frequency of restorer genes decreases in the population and we come again at the initial point.

The two first phases are not observed in our study; there are no patches of unrestored females, as it has been observed in Thymus vulgaris (Dommée and Jacquard, 1985). Both populations would correspond to different stages of the second phase, population $\mathrm{B}$ being at an earlier stage than population $\mathrm{A}$. Indeed, while the $\mathrm{S}$ cytoplasm has already invaded 80 per cent of both populations, restoration is also present, with a higher level of restoration in population $\mathrm{A}$. The marked change in the proportion of sex phenotypes towards a lower frequency of females, detected in population B, would be due to the dynamical process of invasion by nuclear restorer genes. This is well illustrated by the variation of the level of restoration between the $\mathrm{G}_{0}$ and $\mathrm{G}_{1}$ generations (table 4).

The rate of decrease of female frequency in the expected $(n+1)$ th generation has been observed to be proportional to the female frequency in the preceding one. In the same way, Krohne et al. (1980) observed a decrease of female frequency in eight natural populations of Plantago lanceolata related to the female frequency in the populations, although similar results have not been found in Thymus vulgaris (Couvet et al., 1985). We suggest that the speed of invasion of a population by restorer genes is related to pollen flow, which is probably very different between anemophilous species like Beta or Plantago and entomophilous species like Thymus. The minimal plant distance to maintain purity of plant varieties depends on the reproductive system (self or cross-fertilization), and within each system, there is an increase in the minimal distance from entomophilous species to anemophilous species (Levin and Kerster, 1974). In Thymus, pollen transfer by bees is very limited (0.50 to $1 \mathrm{~m}$ (Brabant et al., 1980; Belhassen et al., 1987)), whereas in anemophilous species such as Beta, pollen flow is less limited: $>4.50 \mathrm{~m}$ (Archimowitsch, 1949) and 50 per cent of pollen is present $100 \mathrm{~m}$ from the source (Levin and Kerster, 1974). As a consequence, the process of invasion by restorer genes in a gynodioecious population should be faster in anemophilous species.

The distribution of sex phenotypes in the expected $\mathrm{G}_{1}$ has been estimated using segregations obtained from the seeds produced in the $G_{0}$ generation. The study of the dynamics of change in female frequency in natural populations should take into account the life-history traits of the species: Beta maritima is a short-lived perennial. In our case, only six plants (four hermaphrodites and two females) in population $\mathrm{A}$ and three plants 
(two hermaphrodites and one female) in population $\mathrm{B}$ were still alive the next year because the winter 1984-85 was particularly severe. The speed of the invasion of restorer genes will therefore depend on the pattern of recruitment of young individuals into the populations in the next generation (from the seed bank and the seeds of the current year).

Acknowledgements This work was supported by the ATP Biologie des Populations no. 098493 of the CNRS to Ph. Vernet and $\mathbf{R}$. Jean. The first author received a research fellowship from the Ministère de l'Industrie et de la Recherche. We are indebted to Prof. Michaelis' team for the molecular analysis of plant material. We wish to thank J. Bronstein, D. Couvet, J. Cuguen, C. Gliddon, P. H. Gouyon, D. A. Jones, J. M. M. van Damme and $H$, van Dijk for critically reading an earlier draft of the manuscript.

\section{REFERENCES}

ARCHIMOWITSCH, A. 1949. Control of pollination in SugarBeet. Botanical Review, 15, 613-628.

BELHASSEN, E., DOCKES, A. C., GLIDDON, C. AND GOUYON, P. H. 1987. Dissémination et voisinage chez une espèce gynodioique: le cas de Thymus vulgaris (L.). Genet. Sel. Evol., 19, 307-320.

BELHASSEN, E., TRABAUd, L., COUVET, D. AND GOUYON, P. H. 1989. An example of nonequilibrium processes: gynodioecy of Thymus vulgaris L. in burned habitats. Evolution, 43, 662-667.

BOUTIN-STADLER, v. 1987. Sélection Sexuelle et Dynamique de la Stérilité Mâle dans les Populations Naturelles de Beta maritima. Thèse Doct., USTLFA, Lille (France).

BOUTIN, V., PANNENBECKER, G., ECKE, W., SCHEWE, G., SAUMITOU-LAPRADE, P., JEAN, R., VERNET, PH. AND MICHAELIS, G. 1987. Cytoplasmic male sterility and nuclear restorer genes in a natural population of Beta maritima: genetical and molecular aspects. Theory. Appl. Genet., 73, 625-629.

BoUtin, V., JEAN, R., VAlero, M. AND VERnet, PH. 1988 a. La stérilité mâle chez la betterave sauvage. In Bervillé, A. (ed.) "Variabilité Génétique Cytoplasmique et Stérilité Mâle Cytoplasmique", Les Colloques de l'INRA.

BOUTIN, V., JEAN, R., VALERO, M. AND VERNET, PH. $1988 b$. Gynodioecy in Beta maritima. Acta Oecol. Oecol. Plant., 9, 61-66.

BRABANT, PH., GOUYON, P. H., LEFORT, G., VALDEYRON, G. AND VERNET, PH. 1980. Pollination studies in Thymus vulgaris L., Oecol. Plant., 15, 37-45.

CHARLFSWORTH, D. 1981. A further study of the problem of the maintenance of females in gynodioecious species. Heredity, 46, 27-39.

COUVET, D., GOUYON, P. H., KJELlBERG, F. AND VALDEYRON, G. 1985. La différenciation nucléo-cytoplasmique entre populations. CR Acad. Sci., Série III, 300, 665-668.
COUVET, D., BONNEMAISON, F. AND GOUYON, P. G. 1986. The maintenance of females among hermaphrodites: the importance of nuclear-cytoplasmic interactions. Heredity, 57, 325-330.

DELANNAY, X., GOUYON, P. G. AND VALDEYRON, G. 1981. Mathematical study of the evolution of gynodioecy with cytoplasmic inheritance under the effect of a nuclear restorer gene. Genetics, 99, 169-181.

DOMMEE, B. 1973. Recherches sur la Génétique Écologique de Thymus vulgaris L.: Déterminisme Génétique et Répartition des Formes Sexuelles. Thes. Doct. Etat, USTL, Montpellier.

DOMMEE, B., GUillerM, J. L. AND VALDEYRON, G. 1983. Régime de reproduction et hétérozygotie des populations de thym, Thymus vulgaris $L$. dans une succession postculturale. CR Acad. Sci., Série III, 296, 111-114.

DOMMEE, B. AND JACQUARD, P. 1985. Gynodioecy in Thyme, Thymus vulgaris L: Evidence from successional populations. In Jacquard, P., Heim, G. and Antonovics, J. (eds) Genetic Differentiation and Dispersal in Plant, Springer Verlag, Berlin, pp. 141-164.

GOUYON, P. H. AND COUVET, D. 1985. Selfish cytoplasm and adaptation: variations in the reproductive system of thyme. In Haeck, J. and Woldendorp, J. W. (eds) Structure and Functioning of Plant Populations/2, North Holland. Publ. Comp., New-York, pp. 299-319.

GOUYON, P. H., LUMARET, R., VALDEYRON, G. AND VERNET, PH. 1983. Reproductive strategy and disturbance by man. In Mooney, H. and Godron, M. (eds) Disturbance and Ecosystems, Springer Verlag, Berlin, pp. 214-224.

GREGORIUS, H. R., ROSS, M.D. AND GILLET, E. 1982. Selection in plant populations of effectively infinite size: III. The maintenance of females among hermaphrodites for a biallelic model. Heredity, 48, 329-343.

HALLDEN, C., BRYNGELSSON, T. AND BOSEMARK, N. O. 1988. Two new types of cytoplasmic male sterility found in wild Beta beets. Theor. Appl. Genet., 75, 561-568.

KHEYR-POUR, A. 1980. Nucleo-cytoplasmic polymorphism for male sterility in Origanum vulgare L.. J. Heredity, 71, 253260.

KROHNE, D. T., BAKER, I. AND BAKER, H. G. 1980. The maintenance of the gynodioecious breeding system in Plantago lanceolata L.. Amer. Midl. Natur., 103, 269-279.

LEVIN, D. A. AND KFRSTER, H. W. 1974. Gene flow in seed plants. Evol. Biol., 7, 139-220.

OWEN, F. V. 1942. Male sterility in sugar beets produced by complementary effects of cytoplasmic and mendelian inheritance. Am. J. Bot. (abstr.), 29, 692.

ROSs, M. D. 1978. The evolution of gynodioecy and subdioecy. Evolution, 32, 174-178.

Saumitou-Laprade, P. 1989. De la Stérilité Mâle à la Gynodioécie chez Beta maritima: Aspects Génétiques et Moléculaires. Thèse Doct., USTLFA, Lille (France).

SOKAL, R. R. AND ROHLF, F. J. 1981. Biometry, 2nd Edition. Freeman W. H. and Company Ed., New York, $859 \mathrm{pp}$

VAN DAMME, J. M. M. 1983. Gynodioecy in Plantago lanceolata L.: Inheritance of three male-sterility types. Heredity, 50, 253-273. 